\title{
A siroki Nyírjes-tó növényzetének változása 1957 és 2019 között
}

\author{
VOJTKÓ András ${ }^{1}$ és DULAI Sándor \\ Eszterházy Károly Egyetem, Növénytani és Növényélettani Tanszék, \\ 3300 Eger, Leányka u. 6.; ${ }^{1}$ vojtkoa@gmail.com \\ Elfogadva: 2019. november 14.
}

Kulcsszavak: gyapjasmagvú sásos, lápszukcesszió, nádasodás, nyíresedés, tőzegmohás láp, vegetációtérkép.

Összefoglalás: A Nyírjes-tó felfedezésekor - 1957-ben - vegetációtérkép készült a lápról. Ezt követően 32 évvel, 1989 nyarán megismételtük a növényzet felmérését, azonban ez a munka kéziratban maradt. 2019-ben újratérképeztük a lápot, és azt tapasztaltuk, hogy az elkülöníthető 5 fő vegetációs egység a tó felfedezése óta lényegében ugyanaz, csupán a társulások határának némi módosulása tapasztalható. Ezek a társulások: az ingadozó vízszintet elviselő Glycerio-Sparganietum erecti, az úszó Lemnetum minoris, a gyürüszerủen elhelyezkedő Calamagrosti-Salicetum cinereae és a Salici cinereae-Sphagnetum, valamint a belső magterületen a Carici lasiocarpae-Sphagnetum. Néhány növényfaj tömegessége változó a láp különböző pontjain, ezek a későbbiekben eltérő szukcesszionális növényzethez vezethetnek. Megnövekedett a láp északi felében a Phragmites australis, a Betula $\times$ rhombifolia, helyenként a Thelypteris palustris és a Salix aurita dominanciája. A nád terjedésének kiindulópontja már a legkorábban készült vegetációtérképen látható, és expanziója nyomon követhető a többi térképen is. Valószínủleg innen indult el a nyíresedés is az utóbbi 30 évben. Napjainkban 10 méter magas Betula $\times$ rhombifolia példányok állománya található a tó északkeleti részén. A Thelypteris palustris a tó északi felén alkot kisebb úszólápot, terjedése a vízszint változatlanságától függ. A Salix aurita betelepülése szintén az utóbbi 30 évben történhetett, mára egy 5 méter átmérőjü sürü állományt alkot. Az Eriophorum vaginatum populációja csökkenő egyedszámot mutat: a 30 évvel ezelőtti felméréskor még 20 tő volt belőle, jelenleg 5 kisebb zsombék található.

\section{Bevezetés}

A siroki Nyírjes-tó a jelenleg hozzáférhető térképek adatai alapján a Mátra keleti felén, Siroktól nyugatra, a Tarna folyó fölé magasodó Darnó-hegytől (356 m) 2 km-re délkeletre, a Cinegés $(284 \mathrm{~m}$ ) oldalában, $210 \mathrm{~m}$ tszf magasságban található. Északnyugat-délkelet irányban megnyúlt, hozzávetőlegesen 180 méter hosszú és 80 méter széles, kb. $9500 \mathrm{~m}^{2}$ kiterjedésű láp. A korábbi dokumentumok tanulmányozása során kiderült, hogy a tó az 1941-ben kiadott „Magyarország katonai felmérése" elnevezésű térképen szerepel először, az ennél korábbi térképeken (I., II., III. Katonai Felmérés) még nincs feltüntetve.

A láp első kutatói Máthé Imre és Kovács Margit voltak, akik 1957 nyarán fedezték fel a lápot és számoltak be a növényzet akkori állapotáról (MÁTHÉ és KovÁcs 
1958). Boros Ádám több alkalommal is járt a lápon, és gyüjtéseinek eredményeit beépítette összefoglaló művekbe, vagy adatait közlésre másoknak átengedte (Boros 1915-1971, 1964, 1968). Bakalárné Sütő Ibolya 1981-ben találta meg itt a Sphagnum fimbriatum-ot, majd később Penksza Károly és munkatársai végeztek elemanalízist a Nyírjes-tó különböző növényfajaiból (BAKALÁrNé 1981, PENKszA et al. 1994). A hazai lápok monografikus feldolgozása Lájer Konrád nevéhez kötődik. Ehhez az összefoglaló műhöz készült újra cönológiai felvétel a láp növényzetéről, a Carici lasiocarpae-Sphagnetum tabelláját találjuk meg benne (LÁJER 1998a). Ezt követően Szurdoki Erzsébet publikált rendszeresen a láp tőzegmoha fajairól, vízkémiai eredményeiről. Összehasonlítva a térség tőzegmohás lápjainak paramétereit, megállapította a siroki víz különbözőségét a keleméri és az egerbaktai lápétól is (SzURDOKI 2003, 2005, 2017, SzURDOKI és ÓDOR 2004). Nagy Jánossal együtt megírta ÉszakMagyarország tőzegmohás lápjainak összefoglalását, amelyben Sirok is szerepel (SzURDoKI és NAGY 2002). Jakab Gusztáv és Sümegi Pál a Nyírjes-tó tőzegfúrásainak eredményeként pollenanalitikai és makrofosszília vizsgálatokat végeztek. A láp hozzávetőleges korát 9-10 ezer évben állapították meg, és felhívták a figyelmet számos, korábban a lápon előforduló, ma már ritka vagy eltűnt fajra. Így szerepel a rétegekben a Carex limosa, és dominánsnak tünik az Eriophorum vaginatum (JAKAB és SÜMEGI 2010, JAKAB et al. 2010). A Nyírjes-tó paleoökológiában betöltött fontos szerepére és kiemelt jelentőségére hívták fel a figyelmet Náfrádi Katalin és munkatársai, akik a korábbi tőzegfúrás eredményeiből állítottak fel modellt az egész Kárpát-medence területére (NÁFRÁdi et al. 2013). Az 1990-es évek közepén felfedezett új jövevény tőzegáfonya (KRÖEL-DULAY 1995, LÁJER 1998b) faji hovatartozását módosítják Nagy János és munkatársai, miszerint a lápon nem a korábban vélt Vaccinium oxycoccos él, hanem a V. microcarpum (NAGY et al. 2017).

Jelenlegi kutatásaink célja a 60 éve felfedezett Nyírjes-tó aktuális növényzeti állapotának rögzítése, bemutatása, és összehasonlítása a korábban készült térképekkel és kutatásokkal. A napjainkban tapasztalható dominanciaviszonyok alapján vázlatot szeretnénk adni a lehetséges szukcessziós utakról, ami alapján az esetleges természetvédelmi beavatkozások is tervezhetők.

\section{Anyag és módszer}

2019 nyarán júliustól szeptemberig végeztük a terepmunkát. Ez a láp többszöri bejárását, GPS koordináták rögzítését, valamint a növényzet felvételezését és drónfelvételek készítését foglalta magában. A növényzeti határokat Garmin Etrex 10 készülékkel, több mint 200 mérési pont alapján állapítottuk meg EOV koordináták és mérőszalag segítségével. A mérési pontok felvételekor $2 \mathrm{~m} \times 2$ m-es kvadrátokban készítettünk cönológiai felvételeket, összesített tabellájukat az egyes társulások tárgyalásánál használjuk fel. 
Korábban, 32 évvel a láp felfedezését követően is térképeztük a Nyírjes-tó növényzetét. 1989 nyarán a tó helyzetét és a társuláshatárokat sokszögeléssel (Zeiss Theo 020 típusú teodolittal) és acél mérőszalaggal rögzítettük. Az összehasonlításhoz ezt a kéziratban maradt térképet is felhasználjuk.

\section{Eredmények}

A lápon, a korábbi felvételezésekhez hasonlóan, 5 fö vegetációs egységet különíthetünk el (MÁTHÉ és KovÁcs 1958). Ezek az ingadozó vízszintet elviselö mocsárzóna (Glycerio-Sparganietum erecti), a hínárnövényzet (Lemnetum minoris), a bokorfüzes (Calamagrosti-Salicetum cinereae), a tőzegmohás füzes (Salici cinereae-Sphagnetum) és a gyapjasmagvú sásos (Carici lasiocarpae-Sphagnetum) (1. ábra). Néhány növényfaj tömegessége változó a láp különböző pontjain, ezek a későbbiekben eltérő szukcesszionális növényzethez vezethetnek. Megnövekedett a láp északi felében a nád (Phragmites australis), a molyhos és bibircses nyír hibridje (Betula $\times$ rhombifolia), helyenként a tőzegpáfrány (Thelypteris palustris) és a füles füz (Salix aurita) dominanciája.

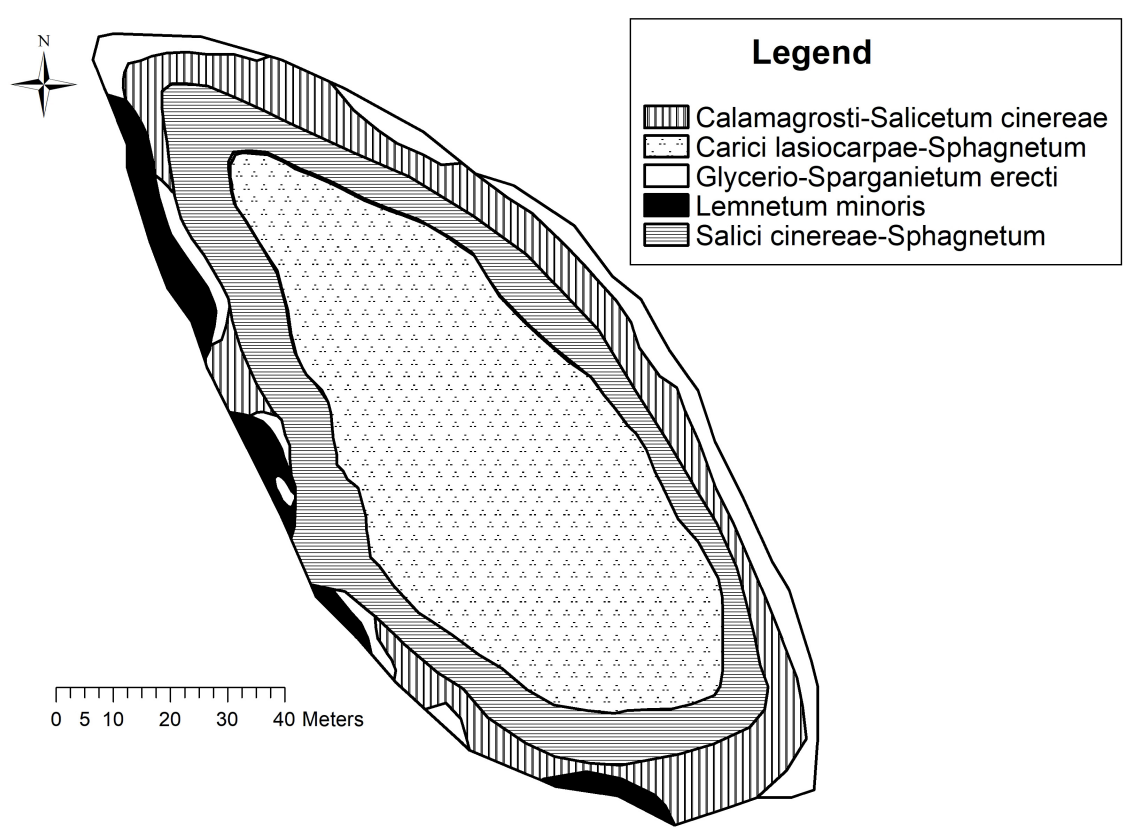

1. ábra. A siroki Nyírjes-tó fó vegetációs egységei 2019-ben (készítette: Vojtkó András).

Fig. 1. Main vegetation classes of the Nyírjes-tó at Sirok (Hungary) in 2019 (prepared by A. Vojtkó). 
A főbb vegetációs egységek jellemzése

1. Glycerio-Sparganietum erecti. Leginkább a lápterület keleti peremén alkot összefüggő zónát, illetve a tó északi és déli csücskét veszi körül sapkaszerüen. 2019 nyarán átlagos szélessége 3-4 méter volt, de az ingadozó vízszint hatásaként még a környező erdő szélén is látni lehetett néhány sás és békabuzogány csomót. Jellemző és tömeges fajai a Juncus effusus, Glyceria maxima, Mentha aquatica. Összesített cönológiai tabellája 25 felvétel alapján az alábbi: Konstancia V: Juncus effusus. K IV: Glyceria maxima, Lycopus europaeus, Mentha aquatica, Salix cinerea, Scutellaria galericulata, Sparganium erectum. K III: Carex elata, Equisetum fluviatile, Lemna minor, Lythrum salicaria, Lysimachia nummularia, Lysimachia vulgaris, Polygonum hydropiper, Riccia fluitans. K II: Calamagrostis canescens, Galium uliginosum, Solanum dulcamara, Typha latifolia. K I: Dryopteris carthusiana, Frangula alnus, Ranunculus repens, Ranunculus sceleratus, Thelypteris palustris, Typha angustifolia.

2. Lemnetum minoris. A láp nyugati oldalán négy különálló foltban térképezhetők az állományai. A korábban készült térképeken is ugyanezeken a területeken találjuk, az aktuális vízellátástól függően esetleg kisebb kiterjedésű foltokban. A tómeder alakja miatt ez és az előző társulás kiterjedése fluktuálhat. Jellemző faja a Lemna minor, kisebb mértékben a Riccia fluitans.

3. Calamagrosti-Salicetum cinereae. A bokorfüzes majdnem teljesen körbeveszi a lápot, csupán a nyugati peremen szakad meg a folyamatos gyürü. Ott, ahol jobban ingadozik a vízszint, szélesebb és összefüggő állományt alkot. A vele szomszédos tőzegmohás füzestől abban különbözik, hogy az ingadozó vízállást ez a növényzeti típus jobban elviseli, amit a szárazra került füztövek megvastagodott gyökföje és a mocsári fajok jelenléte is jól mutat. A fás növényzet átlagos magassága 3 méter, a lágyszárú szint 50-100 centiméteres, borítási értéke 25$30 \%$. Jellemző és tömeges fajai a Juncus effusus, Carex elata, Lysimachia vulgaris. Ritkábbak az Equisetum fluviatile, Scutellaria galericulata és a Thelypteris palustris. Helyenként a nád nagyobb borítású ebben a társulásban is. Összesített cönológiai tabellája 15 felvétel alapján az alábbi: Konstancia V: Juncus effusus, Salix cinerea. K IV: Carex elata, Lysimachia vulgaris. K III: Calamagrostis canescens, Phragmites australis, Solanum dulcamara. K II: Athyrium filix-femina, Dryopteris carthusiana, Equisetum fluviatile, Frangula alnus, Lemna minor, Lycopus europaeus, Lythrum salicaria, Mentha aquatica, Polygonum hydropiper, Scutellaria galericulata. K I: Betula pubescens, Sparganium erectum, Thelypteris palustris.

4. Salici cinereae-Sphagnetum. Összefüggő zárt gyűrűt alkot a belső lápterület körül. A nyugati peremszélen, az itteni állandóan kedvező vízviszonyok miatt, a Nyírjes-tó mederszéléig is kihúzódik. Az előző társulástól az állandó vízborítás különíti el, mert a szárazabb években a vízszint csökkenésével a lápi fajok és 
a tőzegmohák beljebb húzódnak, viszont a csapadékosabb időszakban még nem tudnak olyan ütemben terjedni, mint ahogyan a vízszint a part felé húzódik, így ott inkább a mocsári növények tudnak megélni. Ez az időszakos vízszint fluktuáció alakítja és különíti el a két füzes társulást. A fás növényzet magassága átlagban itt is 3 méter, a lágyszárú szint kb. 25-30\%-os borítású, a mohaszint pedig 90-100\%-os lefedettségü. Fajai között uralkodnak a tőzegmohák: a Sphagnum palustre, S. magellanicum, S. fimbriatum (Orbán és VAjda 1983, Szurdoki 2003). A lágy szárú szintben jellemző és uralkodó faj a Lysimachia vulgaris, helyenként pedig a nád borítása nő meg. Új előfordulás ebből a társulásból a Dryopteris dilatata. A láp északi felén néhány, 10 métert is meghaladó magasságú hibrid nyír egyed (Betula $\times$ rhombifolia) is előfordul. Összesített cönológiai tabellája 25 felvétel alapján az alábbi: Konstancia V: Lysimachia vulgaris, Salix cinerea. K III: Carex lasiocarpa, Dryopteris carthusiana, Equisetum fluviatile, Frangula alnus, Juncus effusus. K II: Betula pubescens incl. rhombifolia, Carex elata, Phragmites australis, Scirpus sylvaticus, Thelypteris palustris. K I: Athyrium filix-femina, Calamagrostis canescens, Dryopteris dilatata, Glyceria maxima, Quercus petraea, Quercus robur, Sparganium erectum.

5. Carici lasiocarpae-Sphagnetum. A láp belső magterületén található. Jellemzi a Carex lasiocarpa dominanciája és a különböző tőzegmoha fajok süppedős szőnyege (Sphagnum angustifolium, S. cuspidatum, S. fallax, S. fimbriatum, S. magellanicum, S. obtusum, S. palustre; SzURDOKI 2003). A lágyszárú növényzet magassága $\mathrm{kb} .50 \mathrm{~cm}$-es, borítása 60, helyenként 75\%. Jellemző fajai az előzőeken túl a Carex elata és a Lysimachia vulgaris. A láp déli részén a Betula pubescens fiatal egyedei fordulnak elő néhol szálanként, a láp szélei felé pedig sűrübben. Néhány Populus tremula is megtalálható itt. A láp északi részén a nád eltérő sűrüségben borítja a területet. Itt elkülöníthetünk egy $25 \%$ alatti nád borítású és egy $25 \%$ feletti dominanciájú területet. A sűrűbb nádasban megtelepedett a Salix aurita egy 5 méter átmérőjű állománya is, valamint jelentős ebben a nádasban a hibrid nyírek (Betula $\times$ rhombifolia) borítása is. A gyapjasmagvú sásos jövevényfajai a Drosera rotundifolia és a Vaccinium microcarpum. Felfedezésük az 1990-es évek közepén történt, bekerülésük nagy valószínűség szerint behurcolódás eredménye (KRÖELDulay 1995, LÁjer 1998b, Szmorad és Barabás 1999, Szurdoki és Nagy 2002, SzURDOKI 2005). A tőzegfúrásokból korábban nem mutathatók ki (JAKAB és SÜMEGI 2010). Ebben a társulásban kis foltja van az Eriophorum vaginatumnak is, korábbi időszakokban ez a faj nagyobb mennyiségben élt (JAKAB és SüMEGI 2010). Összesített cönológiai tabellája 15 felvétel alapján az alábbi: Konstancia V: Carex lasiocarpa, Betula pubescens. K IV: Carex elata, Juncus effusus, Lysimachia vulgaris. K III: Salix cinerea. K II: Calamagrostis canescens, Equisetum fluviatile, Frangula alnus, Phragmites australis, Populus tremula, Scirpus sylvaticus. K I: Drosera rotundifolia, Dryopteris carthusiana, Eriophorum vaginatum, Quercus petraea, Scutellaria galericulata, Thelypteris palustris, Vaccinium microcarpum. 


\section{Megvitatás}

A viszonylag kis kiterjedésü Nyírjes-tó összetett lápnövényzetének szukcessziós viszonyait a helyenként tömegesen fellépő fajok dinamikus kapcsolatai alapján vizsgáljuk. Elsőként a nád (Phragmites australis) terjedését és a feltöltődésben betöltött szerepét, majd a nyírfajok (Betula pubescens és $B . \times$ rhombifolia), illetve a tőzegpáfrány (Thelypteris palustris) lokális helyzetét tárgyaljuk. Ehhez felhasználjuk az elsőként készült vegetációtérképet (MÁTHÉ és KovÁcs 1958; 2. ábra), a Dulai Sándor és Kerezsi Jenő által 1989-ben készített és a mai napig kéziratban maradt térképet (3. ábra), végezetül a 2019-ben készült és a jelzett domináns fajok kiterjedését is ábrázoló vegetációtérképet (4. ábra).

Itt kell megemlíteni, hogy az eredeti publikációban szereplő vegetációtérképet (MÁTHÉ és KovÁcs 1958) többen is átvették. A jelmagyarázat viszont minden esetben hibásan került másodközlésre, így az eredeti térkép ismerete nélkül igen zavaró a hibás jelkulcs (PenKsza et al. 1994, JAKAB és SüMEgi 2010, NÁFRÁdi et al. 2013).

A nád szukcesszióban betöltött szerepe jelentős, ami jól megfigyelhető, ha összevetjük a kiterjedését az 1957-es, az 1989-es és a 2019-es térképen (2., 3., 4. ábra). A nád- az üledékminták alapján mintegy 9500-7500 éve kimutathatóan jelen van a lápon (JAKAB és SÜMEGI 2010). Az 1957-es vegetációtérkép szerint a

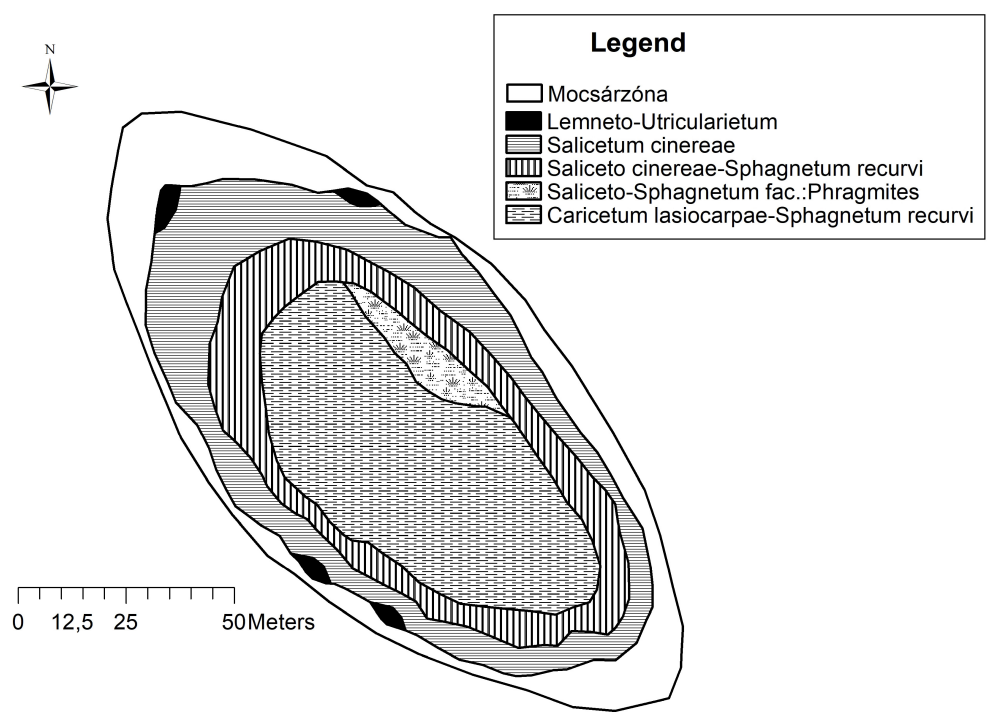

2. ábra. A siroki Nyírjes-tó vegetációtérképe 1957-ből (MÁTHÉ és Kovács 1958).

Fig. 2. Vegetation map of the Nyírjes-tó at Sirok (Hungary) in 1957 (MÁt É and KovÁcs 1958). 


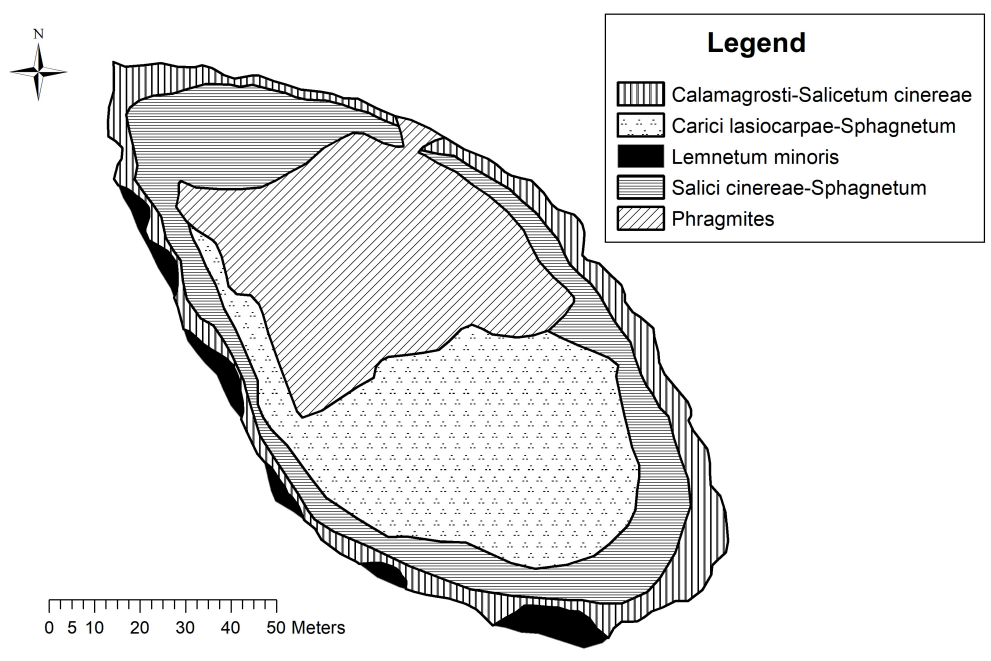

3. ábra. A siroki Nyírjes tó vegetációtérképe 1989-ből (készítette: Dulai Sándor és Kerezsi Jenő). Fig. 3. Vegetation map of the Nyírjes-tó at Sirok (Hungary) in 1989 (prepared by S. Dulai and J. Kerezsi).

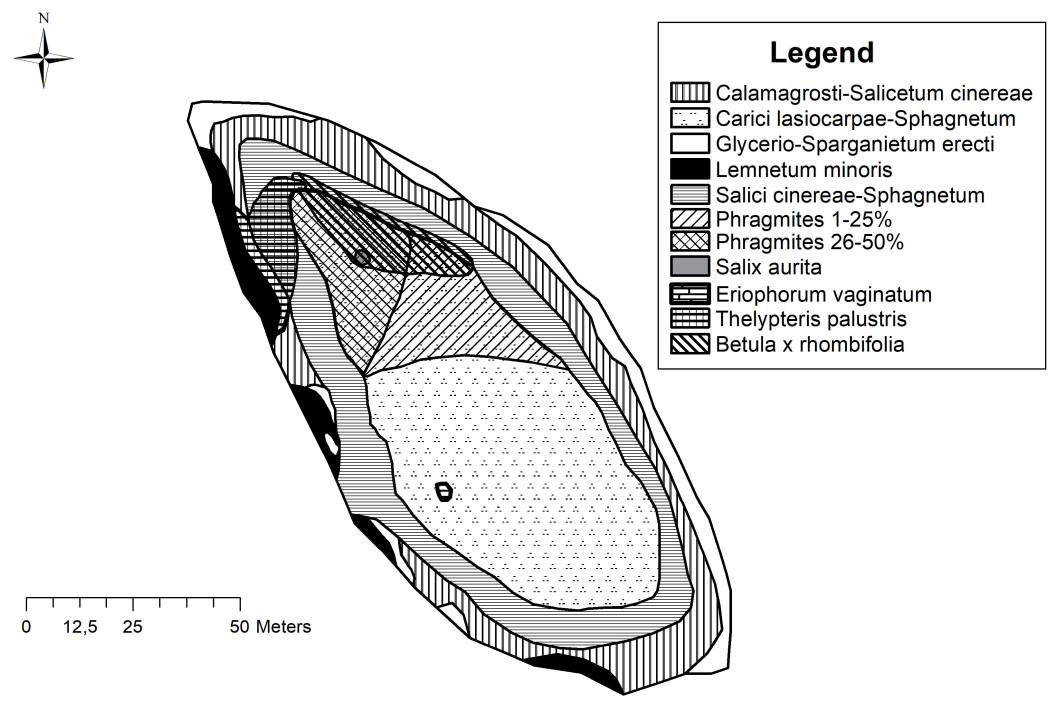

4. ábra. A siroki Nyírjes-tó 2019-ben rögzített vegetációtérképe (készítette: Vojtkó András). Fig. 4. Vegetation map of the Nyírjes-tó at Sirok (Hungary) in 2019 (prepared by A.Vojtkó). 
belső gyapjasmagvú sásos-tőzegmohás keleti szélén kisebb foltot alkot (MÁTHÉ és KovÁcs 1958). Ehhez képest az 1989-ben készült térképen már a belső magterület északi felét is elborítja. A 2019-ben készült térkép megkülönböztet sűrübb (26-50\%) és ritkább (1-25\%) nádborítást a gyapjasmagvú sásos északi részén (4. ábra). Azon túlmenően, hogy a nád további folyamatos területfoglalása várható, a kiinduló pontnak számító keleti részen dominanciája tovább nőhet, és ezzel párhuzamosan a fás növényzet további megtelepedése és megerősödése lehetséges.

A nyírfajok szerepe a szukcesszióban: A légi fotókon és a drónfelvételeken is kitűnik a láp északi felének viszonylagos erdősültsége (5-6. ábra). Itt a fák jóval magasabb termetủek, mint a déli részen, és állományuk is sủrủbb. Ennek a területnek a leggyakoribb fás szárú fajai a Betula $\times$ rhombifolia, a $B$. pubescens, a Salix cinerea és a Frangula alnus. A legkorábbi vegetációtérkép (MÁtнé és KovÁcs 1958) még nem ábrázolja, így ennek a vegetációfoltnak a megerősödése feltehetően az utóbbi 30 évben következett be. A lágy szárú növényzete dús, magasabb borítási értékkel szerepel a Phragmites australis, a Lysimachia vulgaris, az Equisetum fluviatile. A tőzegmoha szőnyeg összefüggően borítja az aljzatot. Felvetődhet a kérdés, hogy lehetséges-e nyíres tőzegláppá alakulnia ennek a területnek? Megítélésünk és keleméri tapasztalatunk szerint a viszonylag kis kiterjedés, a sűrű fás növényzet nem kedvez az ilyen irányú szukcessziónak.

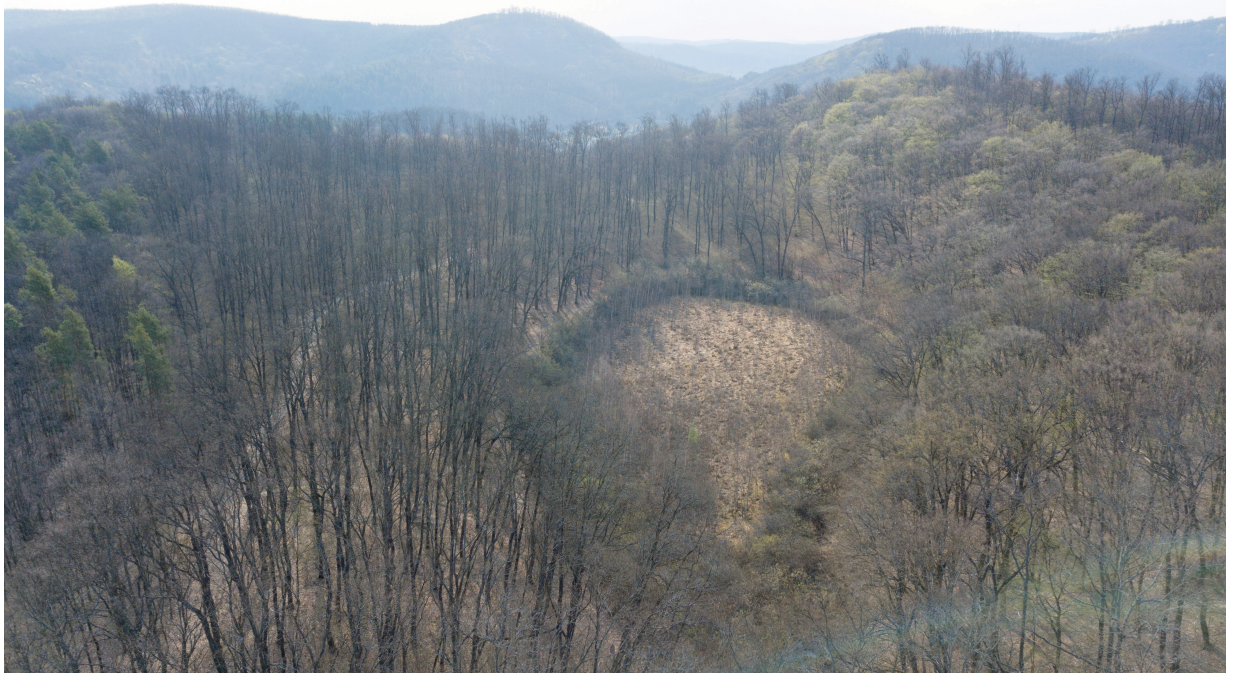

5. ábra. A siroki Nyírjes-tó drónfelvételen 2019-ben tavasszal, északi irányból (a felvételt készítette: Kozma Attila)

Fig. 5. Drone-image of the Nyírjes-tó at Sirok (Hungary) taken from the North in spring 2019 (made by A. Kozma). 
Mindeközben megjegyzendő, hogy a természetvédelmi kezelést ellátó Bükki Nemzeti Park Igazgatóság, ahogy a 2000-es években is, úgy a közeljövőben is tervezi a fás szárú növényzet (Populus tremula, Betula $\times$ rhombifolia) gyérítését, a szukcessziós folyamatok lassítását.

A Nyírjes-tó főként északi részén a Thelypteris palustris jellegzetes állománya fordul elö. A sűrű tőzegpáfrányos ingólápszerűen viselkedik, és fás szárú növényzet nem borítja. A felszínen víztükör és szabad vízfelület is van, szemben a láp többi tőzegmohával fedett süppedős részével. A későbbiekben önálló, korábban leírt és jellemzett (LÁJER 1998a) Thelypteridi-Typhetum angustifoliae társulás felé alakulhat a mocsárzóna ezen része. A tőzegpáfrányos foltban előforduló fajok: Carex elata, C. lasiocarpa, Glyceria maxima, Scirpus sylvaticus, Sparganium erectum, Sphagnum spp., Thelypteris palustris, Typha angustifolia. Ugyanakkor jelentős hatással lehet rá a szomszédos, nyírekből (Betula pubescens, $B . \times$ rhombifolia) álló sáv, ahol a láp rögzülése, a fák legyökeresedése elkezdődhetett.

További szukcessziós lehetőség a Salix aurita terjeszkedése a láp északi felén és önálló társulássá alakulása (Salicetum auritae), ilyen hazánkban eddig csupán a Nyugat-Dunántúlon található (BoRHid 2003).

A hüvelyes gyapjúsás (Eriophorum vaginatum) a tőzegfúrás adatai alapján 3900 éve jelen van a lápon (JAKAB és SÜMEGI 2010). A napjainkban megtalálha-

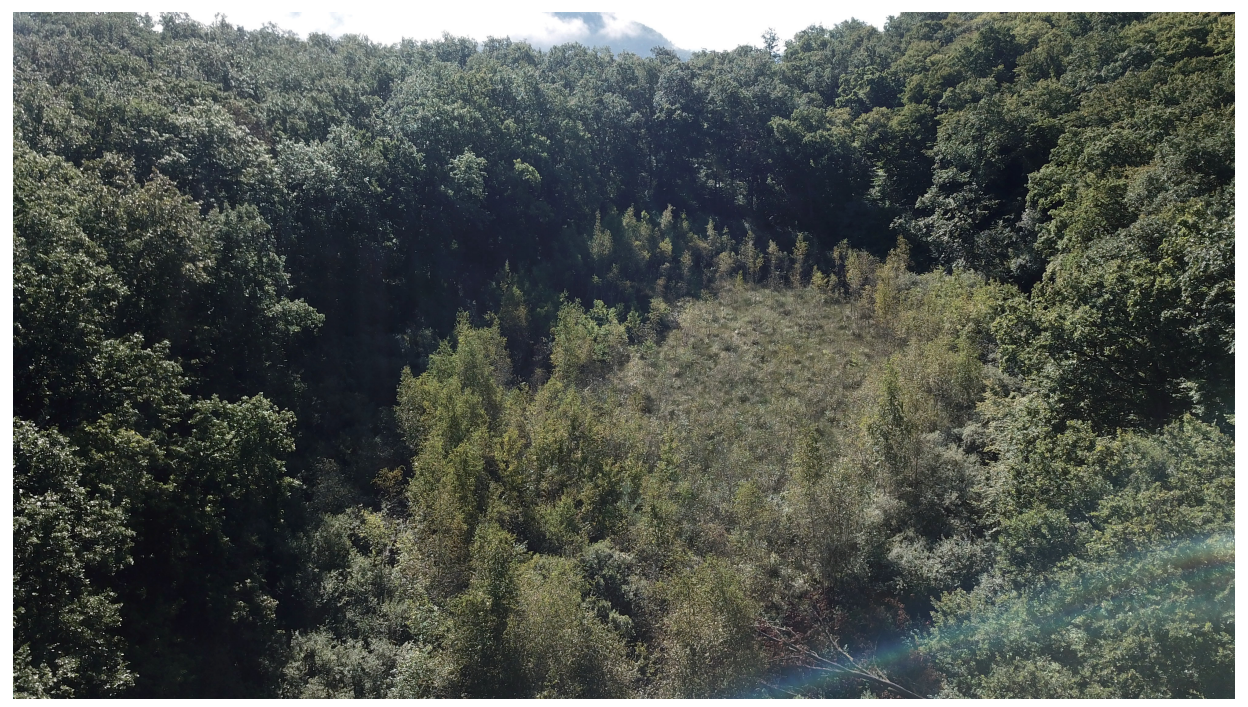

6. ábra. A siroki Nyírjes-tó drónfelvételen 2019-ben nyáron, északi irányból (a felvételt készítette: Kozma Attila).

Fig. 6. Drone-image of the Nyírjes-tó at Sirok (Hungary) taken from the North in summer 2019 (made by A. Kozma). 
Vojtkó A., Dulai S.

tó 5 zsombék az állomány csökkenését mutatja, fóként annak a tudatában, hogy az 1989-es térképezés idején még 20 tő volt belőle.

\section{Köszönetnyilvánítás}

A szerzők köszönetet mondanak a Bükki Nemzeti Park Igazgatóság munkatársainak, Baráz Csabának és Kozma Attilának a drónfelvételek készítéséért, a kutatási feltételek biztosításáért. Köszönjük az Aggteleki Nemzeti Park Igazgatóság és Farkas Tünde segítségét a keleméri Mohos-tavak bejárásában és a vegetációtérképek megrajzolásában. Dulai Sándor köszönetét fejezi ki a TÁMOP (4.2.2A-11/1/KONV-2012-0008) pályázat támogatásáért.

\section{Irodalomjegyzék}

BAKALÁRNÉ SÜTő I. 1981: A Sphagnum fimbriatum a siroki Nyírjes-tó átmeneti lápján. Folia Historico-naturalia Musei Matraensis 7: 161-162.

BorHidi A. 2003: Magyarország növénytársulásai. Akadémiai Kiadó, Budapest, 610 pp.

Boros Á. 1915-1971: Florisztikai jegyzetek. Kézirat. MTM Tudománytörténeti Tára, Budapest Boros Á. 1964: A tőzegmoha és a tőzegmohás lápok Magyarországon. Vasi Szemle 18: 53-68. Boros Á. 1968: Bryogeographie und Bryoflora Ungarns. Akadémiai Kiadó, Budapest, 466 pp.

JakAb G., SÜMEgI P. 2010: Preliminary data on the bog surface wetness from the Sirok Nyírjes-tó peat bog, Mátra Mts, Hungary. Central European Geology 53(1): 43-65. https://doi.org/10.1556/CEuGeol.53.2010.1.3

JAkAb G., SÜMegi P., Szurdoki E. 2010: Paleoecology of peatlands - Quaternary climate reconstructions from Hungary. In: Veress B., Szigethy J. (eds): Horizons in Earth Science Research, Vol. 2, Nova Science Publishers, pp: 1-33.

KRÖEL-DULAY Gy. 1995: A magyarországi tőzegmohalápok összehasonlító vizsgálata. Szakdolgozat (kézirat), ELTE Növényrendszertani és Ökológiai Tanszék, Budapest. 53 pp.

LÁJER K. 1998a: Bevezetés a magyarországi lápok vegetáció-ökológiájába. Tilia 6: 84-238.

LÁJER K. 1998b: Az Aldrovanda vesiculosa L. újabb előfordulása és egyéb adatok Magyarország flórájának ismeretéhez. Kitaibelia 3(2): 263-274.

MÁTHÉ I., KovÁcs M. 1958: A Mátra tőzegmohás lápja. Botanikai Közlemények 47(3-4): 323-331.

Náfrádi K., Jakab G., SÜmegi P., SZelepcsényi Z., Töröcsik T. 2013: Future climate impacts in woodland and forest steppe based on Holocene paleoclimatic trends, paleobotanical change in central part of the Carpathian Basin (Hungary). American Journal of Plant Sciences 4(6): 1187-1203. https://doi.org/10.4236/ajps.2013.46147

Nagy J. Gy., Zsinka B., Verebélyi V., Zorkóczy O. K., Tyler T. 2017: A Vaccinium microcarpum (Turcz. ex Rupr.) Schmalh. Magyarországon. Kitaibelia 22(1): 71-76. https://doi.org/10.17542/kit.22.71

ORBÁN S., VAJDA L. 1983: Magyarország mohaflórájának kézikönyve. Akadémiai Kiadó, Budapest, $518 \mathrm{pp}$.

PenksZa K., Turcsányi G., Kovács M. 1994: A siroki Nyírjes-tó tőzegmohalápjának elemkatasztere. Botanikai Közlemények 81(1): 29-41.

Szmorad F., Barabás S. 1999: Tőzegáfonya - Vaccinium oxycoccos L. Tilia 7: 69-77.

Szurdoki E. 2003: Peat mosses of North Hungary. Studia botanica hungarica 34: 55-79. 
SZURDOKI E. 2005: Magyarországi tőzegmohák elterjedése és egyes fajok vízkémiai igényének vizsgálata. Doktori értekezés (kézirat). Eötvös Loránd Tudományegyetem, Biológiai Doktori Iskola, $140 \mathrm{pp}$.

SZURDOKI E. 2017: Water chemical relations and water table of North Hungarian mires. Studia botanica hungarica 48(2): 199-224. https://doi.org/10.17110/studbot.2017.48.2.199

Szurdoki E., NAgY J. 2002: Sphagnum dominated mires and Sphganum occurrences of NorthHungary. Folia Historico-naturalia Musei Matraensis 26: 67-84.

SZURDOKI E., ÓDOR P. 2004: Distribution and expansion of Sphagnum fimbriatum Wils. in Hungary. Lindbergia 29: 136-142.

\title{
Vegetation changes in the Nyírjes-tó peat bog at Sirok (Hungary) be- tween 1957 and 2019
}

\author{
A. VOJTKÓ ${ }^{1}$ and S. DULAI \\ Deparment of Botany, Eszterházy Károly University, \\ H-3300 Eger, Leányka u. 6; ${ }^{1}$ vojtkoa@gmail.com
}

Accepted: 14 November 2019

Key words: birch encroachment, bog succession, Carici lasiocarpae-Sphagnetum, peat bog, reed encroachment, vegetation map.

The Nyírjes-tó at Sirok (Hungary) was discovered in 1957 and its vegetation was mapped for the first time in the same year. 32 years later, in the summer of 1989, we repeated the vegetation survey, but the resulting map has not been published yet. When we surveyed the peat bog again in 2019, we found that the original 5 main vegetation classes stayed the same since the first mapping, and only a slight shift in their borders can be observed. The main plant associations encountered were the following: Glycerio-Sparganietum erecti (where water level fluctuations need to be tolerated), Lemnetum minoris (free floating), Calamagrosti-Salicetum cinereae and Salici cinereae-Sphagnetum (circular around the core), and Carici lasiocarpae-Sphagnetum (the inner core). The abundance of species is different between the zones of the peat bog due to the different successional stages. The dominance of Phragmites australis, Betula $\times$ rhombifolia, Thelypteris palustris and Salix aurita has increased significantly in the northern part of the bog. The original range of Phragmites is clearly visible on the first vegetation map, and its area expansion can be followed on the more recent maps. It is most likely that the encroachment of Betula $\times$ rhombifolia started from the 
same locus as did for Phragmites 30 years ago. Today, a stand of $10 \mathrm{~m}$ high birch individuals dominates the north-eastern part of the bog. On the northern part, a floating bog of Thelypteris palustris has established, which is expanding depending on the stability of the water level. Since the time 30 years ago, when Salix aurita most likely first established in the bog, it has developed a dense stand of individuals reaching $5 \mathrm{~m}$ in diameter. In contrast to the spread of the above-mentioned species, the population of Eriophorum vaginatum is rapidly decreasing. In the survey 30 years ago, we recorded 20 individuals, while only 5 smaller tussocks can be found today. 